\title{
Erratum to: Spectral and Morphological Studies of Nanocrystalline Silicon Thin Films Synthesized by PECVD for Solar Cells
}

\author{
P. M. Anbarasan • P. Senthilkumar • S. Manimegalai • \\ M. Geetha $\cdot$ K. Vasudevan • V. Ravi • D. Deivasagayam • \\ V. Aroulmoji
}

Published online: 20 July 2010

(C) Springer Science+Business Media B.V. 2010

Erratum to: Silicon (2010) 2:7-17

DOI 10.1007/s12633-009-9028-9

The original submitted version of this article unfortunately contained mistakes.

Dr. S. Moorthy Babu had been accidently added as a coauthor during the submission of the manuscript and his name should be removed as one of the co-authors.

Reference 36 of the article should be changed to read:

36. (a) Ram SK, Islam MN, Cabarrocas PR, Kumar S (2008) Thin Solid Films 516 (2008) 6863-6868: (b) Ram SK (2006) Ph.D thesis, I.I.T. Kanpur, India.

The online version of the original article can be found at http://dx.doi. org/10.1007/s12633-009-9028-9.

P. M. Anbarasan $(\varangle) \cdot$ P. Senthilkumar $\cdot$ S. Manimegalai $\cdot$

M. Geetha $\cdot$ K. Vasudevan • V. Ravi

Department of Physics, Periyar University,

Salem 636011 Tamilnadu, India

e-mail: anbarasanpm@gmail.com

D. Deivasagayam

Nanorobotics Group, Department of Engineering Materials,

University of Sheffield,

36, Hurlfield, Avenue,

Sheffield S12 2TN, UK

V. Aroulmoji

PROTOS Research Institute,

Via Flavia 23/1, C/O Sviluppo Italia,

Trieste 34148, Italy 